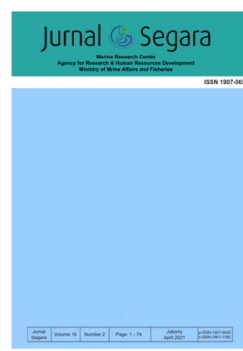

JURNAL SEGARA

http://ejournal-balitbang.kkp.go.id/index.php/segara

ISSN : 1907-0659

e-ISSN : 2461-1166

Accreditation Number: 766/AU3/P2MI-LIPI/10/2016

\title{
EFFECTIVITY OF NORMAL CONCRETE AND CLAMSHELL AS MATERIALS OF ARTIFICIAL PYRAMID REEF AT PASIR PUTIH BEACH, SITUBONDO - INDONESIA
}

\author{
Rudhy Akhwady1), Muhammad Akhyar Maududi'2), Dwi Chandra Dewi' ${ }^{2)}$ \& Oktiyas Muzaky Luthfi' ${ }^{2)}$ \\ 1)Ministry of Marine Affairs and Fisheries Indonesia \\ 2)Fisheries and Marine Science Faculty, Brawijaya University (Malang, Indonesia)
}

Received: 17 October 2019; Revised: 6 November 2020; Accepted: 24 Maret 2021

\begin{abstract}
The bivalve anadara grandis is one of the most abundant shells which are easy to find in Indonesian waters. The number of clams consumed is directly proportional to the amount of clamshell waste, which the most part is only disposed into waste. Coral reef has a very important purpose in supporting activities in coastal areas. Artificial reef is a structure that has aim to restore the biological purpose coral reef that have been damaged. This study aims to compare the effectiveness of the use of normal concrete (made from sand, cement dan splits only) than clamshell mixture as materials of artificial reef. A field research was conducted in Pasir Putih, Situbondo, with visual descriptive method (transect with a quadrant of $25 \times 25 \mathrm{~cm}$ ) and underwater camera as an aid to facilitate the observation. During the 4-month observation of the drowning, nine types of biotas were found in attaching, with the dominant biota attached to these artificial reef were bivalves, barnacles, and bryozoan. Results show that the total number and density of calcareous biota attached on clamshell concretes are higher than those of standard concretes. So, it could be concluded that the concrete reefs made of clamshells resulted in attachment of biota slightly higher than it of normal concretes and the benefits of both materials can form the coral reef ecosystem well. In particular, the use of artificial reef with a mixture of clamshells is better than normal concrete because its more effective for algae attachment and cheaper because low budget due to the material availability of clamshell presently as damage and wastes in coastal area.
\end{abstract}

Keywords: Artificial reef, normal concrete, clamshell, ecosystem.

Corresponding author:

Jl. Pasir Putih I Ancol Timur, Jakarta Utara 14430. Email: r_akhwady@yahoo.com 


\section{INTRODUCTION}

The Pasir Putih Beach, Situbondo in East Java is known as one of the tourism destination for coral reef and biotas underwater. Several spot of coral reef in Pasir Putih such as Batu Lawang spot in level damaged and critical (Lutfi \&Yamindago, 2008). So, it needs to do a rehabilitation effort to enhance the coral reef condition. The habitat rehabilitation can be done through artificial reef that can be made by using the waste of clamshells.

The blood clam (Anadara grandis) is one of the most abundant clams and easy to find in Indonesian waters. These clams are also widely consumed by the community because of good taste, high protein content and the price is inexpensive. The consumption of clams usually leaves clamshell waste.The big quantity of clams consumed increases with the amount of clamshell waste, which the most part is discarded and a little portion used as raw materials for traditional industries and crafts (Department of Marine and Fisheries of Bangka Belitung, 2015). However, not all of the clamshell waste can be utilized as industrial raw materials and handicrafts. There is a high amount of the dirty and untapped clamshells left to be waste. Therefore, the use of clamshell waste is expected to reduce environmental pollution and increase its economic value and benefits.

Coral reef is an ecosystem in tropical waters composed of marine biota which produce calcium, especially the species of hard coral and calcareous algae, together with other biota living on the seafloor like the types of Mollusca, Echinodermata, Crustaceans,
Porifera,Tunicates and other biotas that live freely in the surrounding waters including several types of plankton and fishes. Coral reef has a very important purpose in supporting restoration activities in coastal areas. Artificial coral reef or more commonly known as artificial reef is one model of building structures that aim at trying to restore the biological purpose of damaged coral ecosystems (Lukens \& Selberg, 2004).

This research uses clamshell waste as base material to make artificial reef forming media and then evaluate it. Concretes drowning aimin rehabilitating or repairing damaged coral habitat (Maududi, 2017) such as used stone ash as artificial reef as restoration (Akhwady et al., 2018). These concretes can be containers for the attachment of coral reef and benthic organisms and become spawning ground, feeding ground, and nursery ground for reef fishes (Guntur, 2011). Ecologically, these concretes were expected to function like a natural coral reef ecosystem. The current work tries to examine the use of clamshell waste as raw material for the manufacture of artificial reef.

\section{METHODOLOGY}

The research was conducted in Batu Lawang Waters, Pasir Putih, Situbondo, East Java which geographically is located at $7^{\circ} 41^{\prime} 37^{\prime \prime} S$ and $113^{\circ} 49^{\prime} 08^{\prime \prime}$ $E$ (Figure 1). The drowning of concretes was started on November 11, 2016.Data were then taken on February 23, 2017 and March 28, 2017.

The proportional dimension of pyramid reefs were installed as $60 \mathrm{~cm}$ (high), $60 \mathrm{~cm}$ (long), $30 \mathrm{~cm}$ (Fig. 2 ), every side had three holes and diameter of $7 \mathrm{~cm}$.

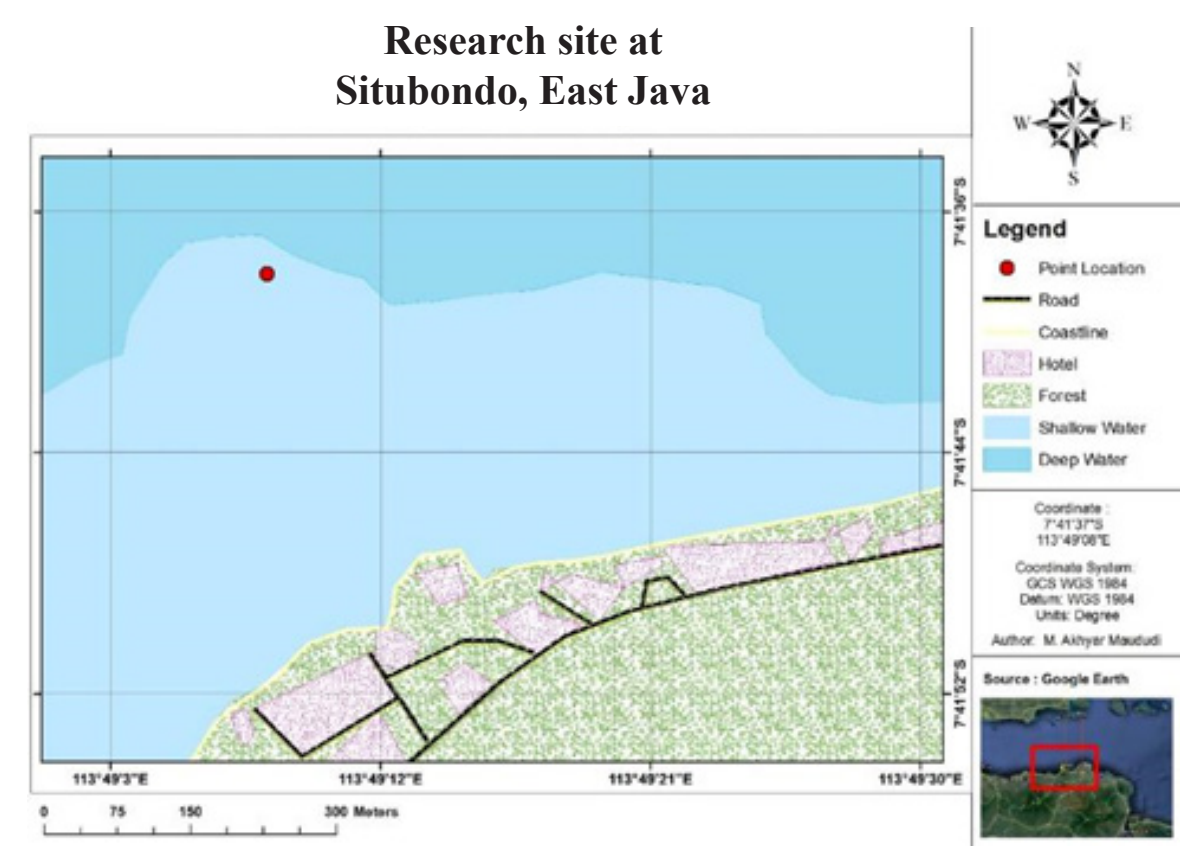

Figure 1. Research Location Map. 
The percentages of materials of normal concrete material were as follows: cement $14 \%$, sand $34 \%$, and stone $52 \%$. The percentages of material composition of clamshell concrete were as follows: cement (14\%), sand $(68 \%)$, and stone (18\%) (Akhwady \& Ridho, 2017).

The data of colonies containing biota on the concrete surface were obtained from visual observation and shooting using three transects with quadrant of 25 $x \quad 25 \mathrm{~cm}$ which were coupled horizontally and photographed from an underwater camera. Therefore, the observation was only focused on the macrobiota (can be seen directly by the eye). Data retrieval was done by photographing each of transects starting from the bottom left of the pyramid then shifted to the right and upper sequentially (Figure 3 ). The next processes were observing and photographing all boxes then recording each biota found. Each visible biota, both alive and dead, was calculated, recorded, and photographed using an underwater camera with macro settings as well as transects as reference of size and wide of the biota to be observed. The data that were obtained then processed and calculated in terms of the percentage of species composition, density, and biota attachment rate on each side of the concretes which was then tested using Mann-whitney statistic test to see the differences of the two kinds of artificial reefs (English et al., 1997; Mahuri, 2014; Railkin, 2004).

\section{RESULTS AND DISCUSSION}

\section{Environmental Parameter Data}

Physical and chemical parameters of data retrieval were done in November 2016, February 2017, and March 2017 (Table 1). The data were taken at the site of the drowning of the artificial reef at Pasir Putih Situbondo.

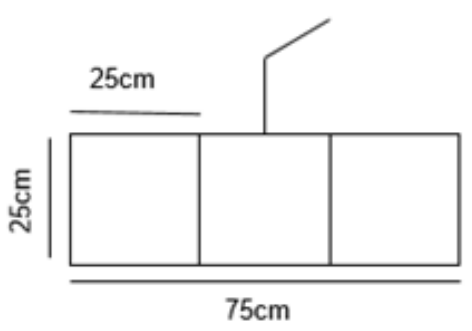

Figure 2. The proportional dimension of the pyramid reefs.

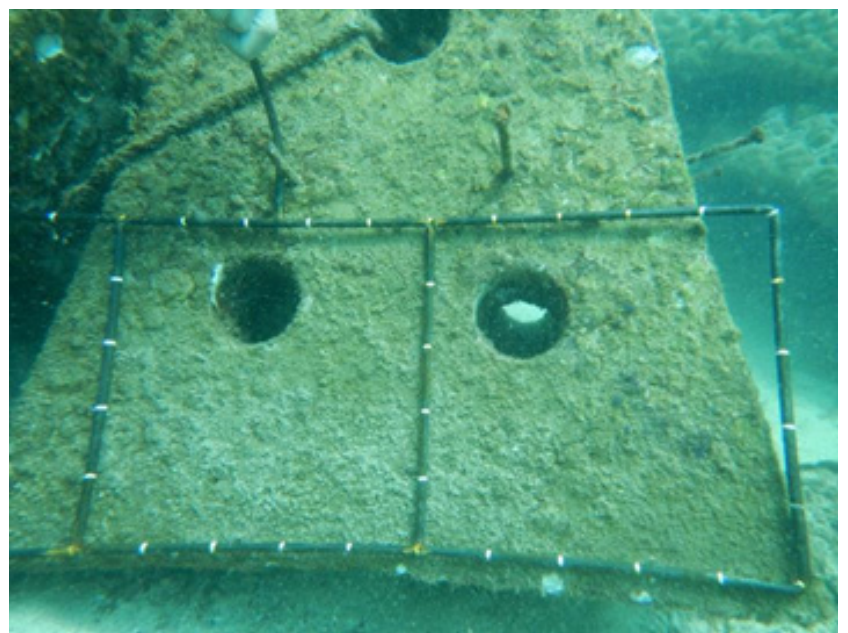

Figure 3. Data retrieval techniques. 
Table 1.

Environmental parameter data

\begin{tabular}{|c|c|c|c|}
\hline \multicolumn{4}{|c|}{ Environmental Parameter Data } \\
\hline Parameter & November 2016 & February 2017 & March 2017 \\
\hline Temperature $\left({ }^{\circ} \mathrm{C}\right)$ & \pm 29.4 & \pm 30 & \pm 29.4 \\
\hline $\mathrm{DO}(\mathrm{mg} / \mathrm{l})$ & \pm 5.1 & \pm 9.4 & \pm 8.13 \\
\hline Salinity (\%o) & \pm 32.2 & \pm 32 & \pm 30.2 \\
\hline Current velocity (m/s) & \pm 0.097 & \pm 0.25 & \pm 0.3 \\
\hline Brightness (m) & \pm 8 & \pm 6.8 & \pm 6.5 \\
\hline $\mathrm{pH}$ & \pm 8.6 & \pm 8.6 & \pm 8.5 \\
\hline Nitrate (mg/l) & - & - & $0.31^{\circ}$ \\
\hline Phosphate (mg/l) & - & - & 4.38 \\
\hline Sedimentation $\left(\mathrm{gr} / \mathrm{cm}^{2} / \mathrm{hr}\right)$ & - & - & 0.308 \\
\hline
\end{tabular}

Those environmental parameter data mentioned above are not used as comparation variables, but only as additional information that the environmental conditions of waters around Pasir Putih Situbondo are relatively stable and vaporable for the rehabilitation of reef ecosystem at the location.

\section{Composition of types of biota}

The results of visual observations done within four months or 137 days after the drowning of artificial reef made of normal concrete and artificial reef made of clamshells mixture, show that there were eight types of biota observable. The total amount of biota in the normal concrete and clamshell concrete were 807 and 1,729 ind $/ \mathrm{m}^{2}$, respectively (Tabel 2 and Table 3).

From the results of identification of biota was found amount of 9 biotas attached in 8 sides of normal concrete (shown in Figure 4) and 9 biotas were attached in 8 sides (shown in Figure 5) for clamshell mixture concrete. Names of biota attachment were barnacle, bivalve, bryozoan, tunicate, sponge, blue green algae, green algae and tube worm. In general, the benthic communities found in this study were pioneering biotas such as bivalve, barnacles, bryozoan, and algae. The main difference seen in both materials lies in the total number of individuals on clamshell concretes were found more than in normal concretes. In

Table 2.

The Amount of Biota on Normal Concretes

\begin{tabular}{lllll}
\hline No. & Name & Phylum & Class & Total \\
\hline 1. & Barnacle & Arthropoda & Cirripedia & 226 \\
2. & Hermit Crab & Arthropoda & Malacostraca & 1 \\
3. & Bivalve & Mollusca & Bivalvia & 504 \\
4. & Bryozoan & Ectoprocta & Gymnolaemata & 65 \\
5. & Tunicate & Chordata & Ascidiacea & 2 \\
6. & Sponge & Porifera & Demospongiae & 2 \\
7. & Blue Green Algae & Cyanobacteria & Cyanophyceae & 4 \\
8. & Tube Worm & Annelida & Annelida & 3 \\
\hline & Total & & & 807 \\
\hline
\end{tabular}

Table 3.

The Amount of Biota on Clamshell Concretes

\begin{tabular}{lllll}
\hline No. & Name & Phylum & Class & Total \\
\hline 1. & Barnacle & Arthropoda & Cirripedia & 271 \\
2. & Bivalve & Mollusca & Bivalvia & 1195 \\
3. & Bryozoan & Ectoprocta & Gymnolaemata & 209 \\
4. & Tunicate & Chordata & Ascidiacea & 15 \\
5. & Sponge & Porifera & Demospongiae & 5 \\
6. & Blue Green Algae & Cyanobacteria & Cyanophyceae & 9 \\
7. & Green Algae & Charophyta & Charophyceae & 24 \\
8. & Tube Worm & Annelida & Annelida & 1 \\
\hline & Total & & & 1,729 \\
\hline
\end{tabular}


addition, hermit crabs found on then normal concretes and green algae found on clamshell concretes.

This is due to the high adaptability of these organisms to various environmental conditions and their resistance against significant changes in environmental conditions. Navarrete \& Castilla (1990) argued that bivalve and barnacle are known to be able to survive in intertidal areas and able to survive in condition of water loss for a long time. Not only that, they are also resistant against temperature changes that are significantly cold when in the water and heat when in the air. They use their shells to maintain body temperature and not to lose water. Such high degree of adaptability and survival and hermaphrodite breeding are likely to cause bivalve, barnacle and bryozoan to compete which then dominate the artificial reef walls.

In addition to the intertidal areas that have significant water and temperature changes, Ermaitis (1984) stated that barnacle can live in estuary waters meaning that resistance range against the difference of salinities is low. This is due to the hard clamshells so that the shells can resist against large changes in environmental conditions such as: strong currents, waves, turbulence, and light.

\section{Biota Density}

Based on Figure 5, it is seen that dominate the normal pyramid reef made of normal concrete was inhabited dominantly by bivalve and barnacle. The density of bivalve is highest with the value in average of $252 \mathrm{ind} / \mathrm{m}^{2}$ The amount is half of the total density of $404 \mathrm{ind} / \mathrm{m}^{2}$, while density of barnacle at least $113 \mathrm{ind} /$ $\mathrm{m}^{2}$. Just like normal concrete, that bivalve and barnacle are also dominating the artificial reef made of clamshell concrete. Highest density of bivalve at least $598 \mathrm{ind} / \mathrm{m}^{2}$ That number is half of the total density of $865 \mathrm{ind} / \mathrm{m}^{2}$, while the density of barnacles of $136 \mathrm{ind} / \mathrm{m}^{2}$.

There are similarities of the three biotas which have the highest density of both types of normal concrete and clamshell concrete i.e. bivalves, barnacles and bryozoan. Significant test for difference densities (shown in Figure 6) use statistical test (Mann-Whitney $\mathrm{U}$ method). It showed that the ratio of three biotas is indicating the real difference of the three biotas on normal concrete and them on clamshell concrete $(P$ $<0.05)$. This is possible because the pyramid reef made of clamshell concretes contain more calcium on the
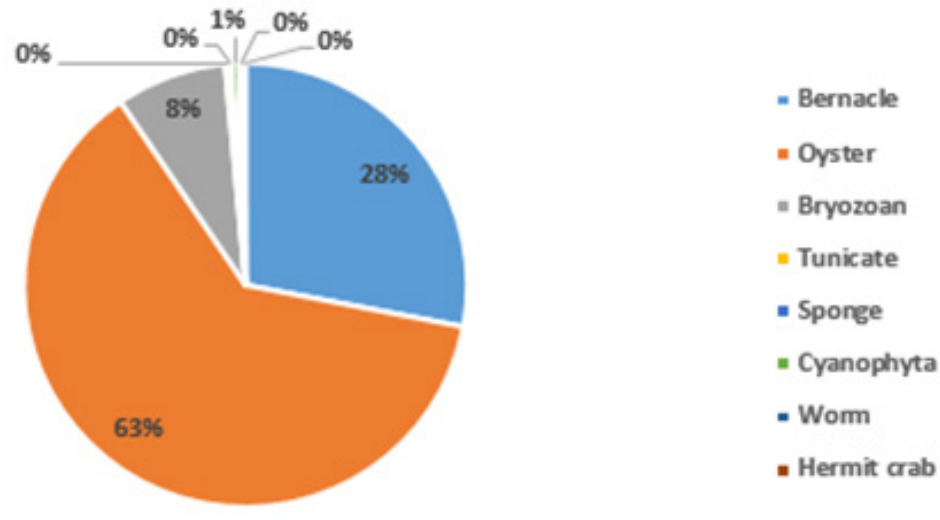

Figure 4. The composition of types of biota on the normal concretes.
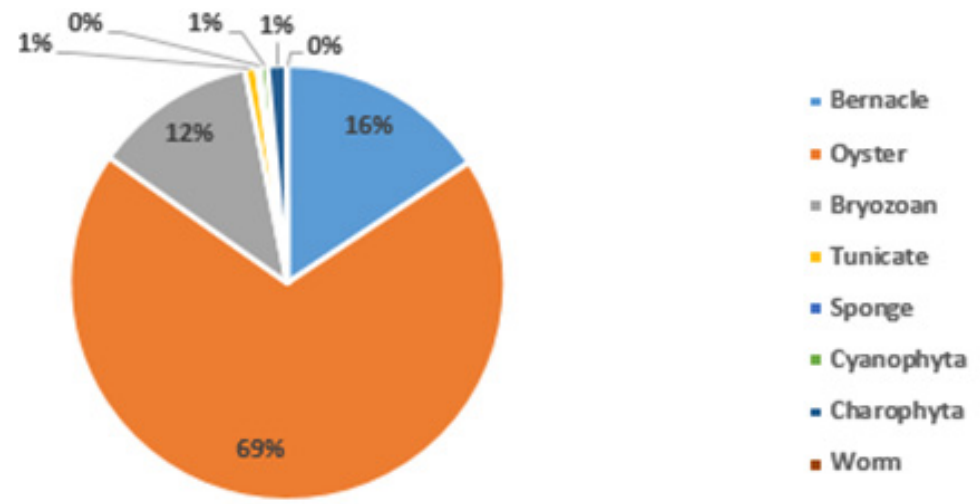

Figure 5. The composition of types of biota on the clamshell concretes. 


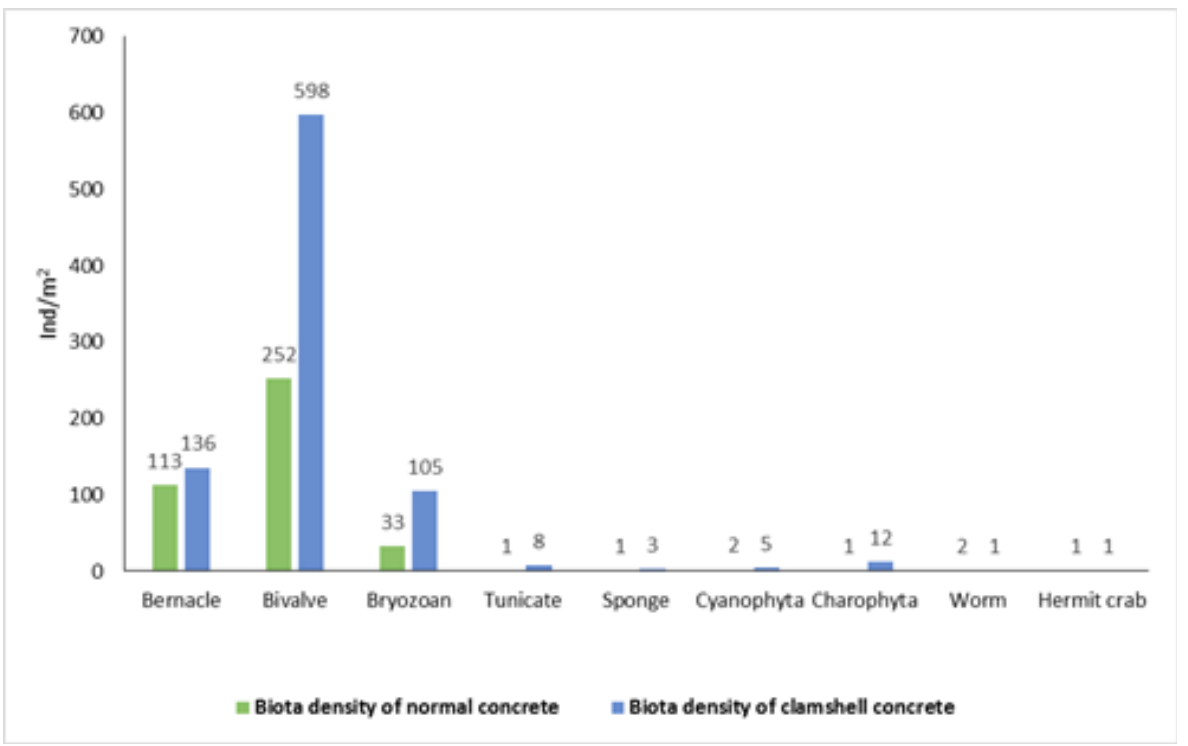

Figure $6 . \quad$ The density of biota.

inside and surface layers. Calcium dissolution is easy to happen when using water, especially if the water contains a lot of $\mathrm{CO}_{2}$ (carbon dioxide). It is then used by some organisms for the calcification process. Some authors stated that barnacle, bivalve and bryozoan are calcareous animals requiring carbon and calcium from the environment for the formation of habitat, shells and other parts of the body in the process of calcification (Peck et al., 2015; Holleman,2017; Ryland, 2005; Banta \& Menasha,1952). This indicates a tendency of biotas with calcareous skeletons to grow on clamshell concrete.

Organisms containing calcareous skeletons require calcium for the formation of shells and some parts of the body. The number of bivalve, barnacle, and bryozoan which are tend to be higher on the artificial reef made of clamshells mixture than the other one because they need calcium for growth and development. This may be because the pyramid reef made of clamshells contains more calcium content on the inside and surface layers. Calcium dissolution is easy to happen when using water, especially if the water contains a lot of $\mathrm{CO}_{2}$ (carbon dioxide). It is then used by some organisms for the calcification process. Moreover, the high abundance of biota compared to others is because of their high adaptability to significant environmental changes. Therefore, most of the biota can reproduce asexually and sexually, most of them are hermaphrodite. It also becomes one of the factors which cause the biota to grow and develop faster than other biota so they can dominate the surfaces of the media.

The result obtained from the Mann-Whitney U-test on the densities of all biota on pyramid reef made of normal concrete and artificial reef made of clamshell mixture is 0.622 . This shows that $P$ value is greater than the confidence interval of $5 \%(P>0.05)$. This indicates that all artificial reefs both made of normal concrete and clamshell mixture do not have much different densities of biota that are distinct. This indicates that there is no significant difference in biota densities related to the difference in the composition of artificial reef. It also may because of the lack of time of observation to see the range of differences in the numbers and densities of the biota, given that the study time was 137 days or 4 months of observation. This is reinforced by the statement of Leonard (2014) who stated that the growth of sticking biota has a less significant effect in a short time.

\section{The Rate of Attachment of Biota}

The rate of attachment of barnacle on the media of the clamshell concrete based on the graph above (Figure 7) is less than normal concrete, while growth rate of bivalve is higher on clamshell concrete than on normal concrete.

The results of measurement of current velocities which are moderate and tending to be low support the spread, attachment, and development of biota on artificial reef. In addition, the current velocity is moderate and supports the formation of new coral reef ecosystem. Fajriet et al. (2014) stated that current velocity and brightness are factors that cause different attachment rates on artificial reef. Strong currents can interfere -the attachment of barnacle larvae to a substrate and it cannot reach the adult phase (Ermaitis, 1984).

The rate of attachment of biota is divided into two phases. First attachment of new larvae from other habitats (migration) in which, usually, larvae are 


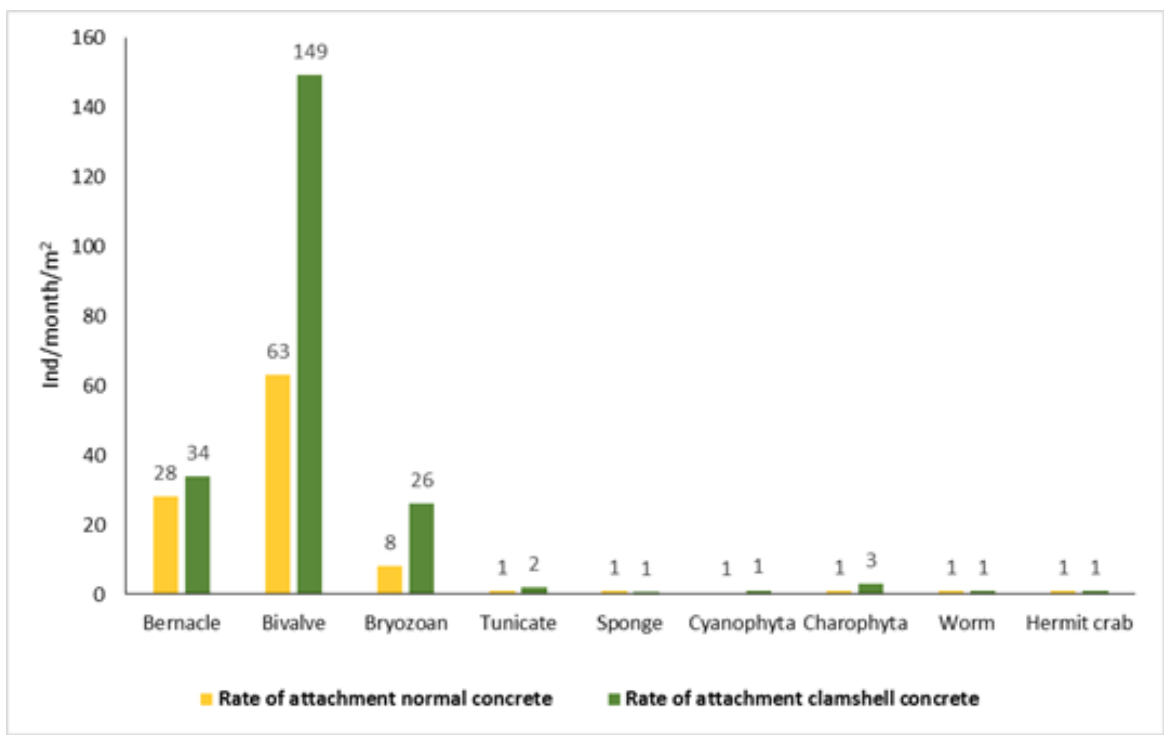

Figure 7. The rate of attachment of biota.

resulting from sexual reproduction. The second is the budding of parent swhich forms a new individual to enlarge the colony. Both barnacle and bryozoan can through the two ways to form colonies (Ermaitis, 1984; Ryland, 2005). Barnacle is hermaphrodite with internal fertilization which is processed in the body cavity. Most of attaching biota can reproduce both asexually and sexually and most of them are hermaphrodites. This is thought to be the main cause of the rapid development of colonies on artificial reef.

Beside of type, the important aspect for biota attachments is surface roughness. Roughness can increase growth acceleration of biotas. This is stated by Fajri et al. (2014), Mahuri (2014), and Marhaeni (2012) that types of surface of the substrate are affecting the rate of attachment. A harsh and hollow substrates tend to be favored by the larvae of the attaching biota. The conclusion is the surface roughness increases the number of colonies of the biota. In Navarrete and Castilla's research (1990), it was suggested that the high rate of attachment is not limited by the large number of larvae, but it depends on the availability of substrate types on a particular area.

The content of some substances on the cement as one of forming mixture materials cause microalgae and various biofilm bacteria such as diatoms to be organisms which are most quickly attached to the media. Some of these substances such as silica, calcium carbonate, iron oxide, magnesium sulphate, are some of the compositions of fertilizers as nutrients for plants (Junus et al., 2007). Accumulation of nutrients on the surface is the main cause of the biota attachment process. Then the accumulation and reproduction of biofilm microorganisms on the surface is a source of nutrients and food for higher tropical level organisms which can then attract multi cellular organisms to gather there. Along with the increase in species composition and growth of benthic organisms, the extent of bivalve and barnacle and algae covers will decrease and shift the dominance of the biota.

The success of an artificial reef can be seen from how much organisms can adapt to the habitat. In Al-Baqarah/2: 164 it is mentioned if Allah already created the earth and the sky include abiotic and biotic elements to realize nature equilibrium. The two elements are interconnected each other and mutually influence. If there is damage on one of these elements, the ecosystem will experience changes. Therefore, actions for the sake of repairing and maintaining the ecosystem in order to remain stable are needed. In both types of media, the presence of pioneering biota has been seen. These biotas are common biotas which usually exist in natural coral reef ecosystem (Lacoste et al., 2014; Sahu et al., 2011). Accumulation of nutrients on the surface is the main cause of the biota attachment process. Then the accumulation and reproduction of biofilm microorganisms on the surface is a source of nutrients and food for higher tropical level organisms which can then attract multicellular organisms to gather there. Along with increasing species composition and growth of benthic organisms, the extent of the covers of algae, bivalve and barnacle will be decreased and shift the dominance of the biota (Odum, 1993; Seaman, 2000).

\section{CONCLUSION}

By the presence of the biotas, it can be stated if the pyramid reef model drowned in the bottom of the waters have been places to live and to find food and also as shelters from predators that will then form a 
separate ecosystem at any given time. The success of ecosystem formation around the artificial reef before being drowned is influenced by a good understanding of the ecology of coral reef as well as the selection of shapes, construction designs, and materials. Both materials are equally able to produce new ecosystem. However, pyramid I reef made of clamshell concrete are more recommended by researchers because the shells are good calcareous organisms and their growth is slightly better than on normal concretes. Not only because of the economic reason, the materials are economic and clamshell concretes are supported by its availability of the clamshells that is abundant in coastal areas.

\section{ACKOWLEDGEMENTS}

The authors thank to Center of Marine Research, Ministry of Marine Affairs and Fisheries Indonesia for funding this research. The main contributors in this paper are Rudhy Akhwady dan Muhammad A. Maududi.

\section{REFFERENCE}

Akhwady, R., \& Ridho, B. (2017). The Influence of Clamshell on Mechanical Properties of NonStructure Concrete as Terumbu buatan. Asian J. Appl. Sci. 5.

Akhwady, R., Tamtomo. P.C., \&Luthfi, O.M. (2018). Used Evaluation of Stone Ash and Clamshell as Concrete Material of Artificial Reef at Pasir Putih Beach, Situbondo - Indonesia. International Journal of Basic \& Applied Sciences IJBASIJENS, 18(2), 1-7.

Al-Baqarah/2: 164, (2006). Al-Quran dan Terjemahnya, 12th ed. Darul Kutub Islamiyah, Jakarta Pusat.

Banta, G., \& Menasha. (1952). The Principal Fouling Organism, Marine Fouling and Its Prevention. Woods Hole Oceanogr. Nav. Inst. Annap. Md. Inst, 580(9), 118-163.

DKP BaBel. (2015, in Indonesian). Participation of Provincial DKP in INOFEC Exhibition. Department of Maritime Affairs and Fisheries. Bangka Belitung Province.

English, S.A., Wilkinson, C., \& Baker, V. (1997). Survey manual for tropical marine resources, 2.ed. ed. Australian Institute of Marine Science, Townsville.

Ermaitis. (1984, in Indonesian). Some Notes About the Balanus Clan (Cirripedia). Oseana, 9(3), 96-101.

Fajri, M.A., Surbakti, H., \& Putri, W.A.E. (2011, in Indonesian). Attachment Rate of Barnacles in
Different Media and Habitats in Kalianda Waters, South Lampung.Maspari J. 3(2), 63-68.

Guntur. (2011,in Indonesian). Coral Ecology on Artificial Reef, 1st ed. Ghalia Indonesia, Bogor.

Holleman, J. (2017). Research to Application: Oyster shell Research Leads to Patent to Deter Biofouling. Natl. Ocean. Atmospheric Adm. NOAA Sea Grant Coll., Oyster Shell 1.

Junus, H.M., Satata, B., \& Arifin, S. (2007, in Indonesian). Effect of Concentrated Biogas Liquid Fertilizer Waste on Chili Growth. Ternak Tropika. 6(2), 88100.

Lacoste, E., Le Moullac, G., Levy, P., Gueguen, Y. \& Gaertner-Mazouni, N. (2014). Biofouling development and its effect on growth and reproduction of the farmed pearl oyster Pinctada margaritifera. Aquaculture, 434, 18-26. doi:10.1016/j.aquaculture.2014.07.012

Leonard, J. (2014, in Indonesian). Effect of Biofouling Growth on Corrosion Rate of Ship Engine Heat Exchanger Material. Proc. Semin. Nas. Tek.Mesin Univ. Trisakti.

Lukens, R.R., \& Selberg, C. (2004). Guidelines for marine terumbu buatan materials. Atl. Gulf States Mar. Fish. Comm.

Luthfi, O.M., \& Yamindago, A. (2008, in Indonesian). Studying the Structure of the Coral Reef Community as a Preliminary Study of the Coral Reef Rehabilitation Program in the White Sand Waters of Situbondo. Prosiding Semnaskan IV FPIK UB.

Mahuri, W. (2014, in Indonesian). Attachment Rate of Barnacles on Different Types of Pier Mast Materials. Essay, Univ. Marit.Raja Ali Haji Riau.

Marhaeni, B. (2012, in Indonesian). Biofouling on several types of rough and smooth surface substrates. Sains Akuatik, 14(1), 41-47.

Maududi, M.A. (2017, in Indonesian). Utilization of Artificial Reef Based on Standard Concrete and Mixed Shelled Concrete as Potential Media in Formation of Artificial Reef Ecosystem in White Sand, Situbondo. Essay. Fakultas Perikanan dan Ilmu Kelautan Universitas Brawijaya, Malang.

Navarrete, S.A., \& Castilla, J.C. (1990). Barnacle walls as mediators of intertidal mussel recruitment: effects of patch size on the utilization of space. Mar. Ecol. Prog. Ser, 68, 113-119. 
Odum, E.P. (1993, in Indonesian). Ecology Fundamentals, 3rd ed. Gajah Mada University Press, Yogyakarta.

Peck, L.S., Clark, M.S., Power, D., Reis, J., Batista, F.M., \& Harper, E.M. (2015). Acidification effects on biofouling communities: winners and losers. Glob. Change Biol. 21, 1907-1913. doi:10.1111/ gcb. 12841

Railkin, A.I. (2004). Marine biofouling: colonization processes and defenses. CRC Press, Boca Raton, FL.

Ryland, J.S.(2005). Bryozoa: An Introductory Overview, er. ed, 28. National Museum, Denisia 16, Austria.

Sahu, G., Achary, M.S., Satpathy, K.K., Mohanty, A.K., Biswas, S., \& Prasad. M.V.R. (2011). Studies On The Settlement and Succession of Macrofouling Organisms In The Kalpakkam Coastal Waters, Southeast Coast of India. Environ. Ind. Saf.Div. RSEG REG Indira Ghandhi Cent.At. Res. India 40, 747-761.

Seaman, W. (Ed.), (2000). Artificial reef evaluation: with application to natural marine habitats, Marine science series. CRC Press, Boca Raton, Fla. 
Pasir Putih Beach, Situbondo - Indonesia (Akhwady, R., et al.) 